\title{
THE EFFECT OF INFORMATION TECHNOLOGIES ON
}

\section{TQM: AN INITIAL ANALYSIS.}

\author{
Angel R. Martínez-Lorente ${ }^{1 *}$ \\ Universidad Politécnica de Cartagena, Cartagena, Spain \\ Cristóbal Sánchez-Rodríguez \\ Wilfrid Laurier University, School of Business \& Economics, Waterloo, Canada \\ Frank W. Dewhurst \\ Manchester School of Management, UMIST, Manchester, United Kingdom
}

\begin{abstract}
Information Technology (IT) and Total Quality Management (TQM) have significantly impacted on most organizations and each has been widely researched. However, there is little well-founded empirical research on the relationship between the two, particularly on the way in which TQM is influenced by IT. This paper presents an investigation of such relationships through a survey of the largest industrial companies based in Spain. The data indicate that the most intensive users of IT perceive a bigger impact on their TQM dimensions.
\end{abstract}

Keywords: Information Technology, Total Quality Management, empirical study

\footnotetext{
${ }^{1}$ Corresponding author: Angel R. Martínez-Lorente. Facultad de Ciencias de la Empresa, Paseo Alfonso XIII, 50, 30203, Cartagena, Spain. Telephone: 3468 325618. Fax: 3468 327008. E-mail: angel.martinez@upct.es * The authors wish to thank the financial support provided by Seneca Foundation for this research.
} 


\section{Introduction}

It is frequently argued that IT is a very important factor in increasing productivity and reducing costs $[1,2,3,4,5]$, although some studies show contradictory results $[6,7,8]$. Evidence of positive and significant returns from IT investment can be found in Brynjolfsson and Hitt [9], Dewan and Min [10] and Kelley [11] whilst Loveman [12], Powell and DentMicalef [13] and Strassmann [14] found that IT had no significant effect on productivity or competitive advantage. Using country-level data, Dewan and Kraemer [15] found that IT investments have a positive and significant effect on GDP output in developed countries but not in developing ones.

Manufacturers and service providers seeking continuous improvements in business performance apply various means for improving quality, reducing costs and increasing productivity. These include Total Quality Management (TQM), Total Productive Maintenance (TPM), Business Process Re-engineering (BPR), Manufacturing Resources Planning (MRP), Just-in-Time (JIT), etc. Weston [5] claims that all these interventions rely on IT, since they act as a feedback mechanism to users who are keen to measure productivity and, in addition, they also serve as the means to get rapid and more accurate information, improve communication links, and facilitate the implementation of advanced tools, systems and modelling techniques. There is little doubt that applications of IT affect all sections and functions of a company, therefore, it is argued that IT also must affect Total Quality Management (TQM). This paper examines the way in which TQM is influenced by IT and the role of IT in TQM interventions.

Before considering the influence of IT on TQM it is necessary to define what is meant by the term TQM. We used the TQM dimensions identified by Ahire et al. [16], Flynn et al. [17] and Saraph et al. [18] to identify the key TQM dimensions used in this study (see Table 1). Accordingly, eight key TQM dimensions were identified: top management support, workforce 
management, employees attitudes and behaviour, customer relationship, supplier relationship, product design process and process flow management. Figure 1 offers a brief description about each TQM dimension.

In recent years quality award programs such as the European Quality Award [19] and the Malcolm Baldrige Award (MBNQA) [20], have brought attention to quality issues and helped to clarify the meaning and the key constituents of quality management [21, 22]. After comparing the key elements included in our TQM definition with the building blocks of the EFQM and MBNQA frameworks (see Table 1) we can conclude that, as a whole, the TQM definition used in this study is consistent with EFQM and MBNQA frameworks. However, there are two exceptions: the product design process and quality data and reporting, which are not considered in the EFQM framework.

Much has been written about how IT might be used to enhance TQM, see for example: Ayers [23], Zadrozny and Ferrazzi [24], Berkley and Gupta [25] and Cortada [26]. Sobkowiak and LeBleu [27] and Pearson and Hagmann [28] emphasise the key roles that information and IT play in TQM. Specific IT applications in various aspects of TQM have been described by: Miller [29], Aiken et al. [30], Goodman and Darr [31], Khalil [32], Kaplan [33], Kock and McQueen [34] and Counsell [35].

Some studies have considered how IT is related to organizational performance measures. For example Byrd and Marshall [36] employed causal model analysis to relate IT investment to organisational performance whilst Rogers et al. [37] examined the relationship between utilisation of IT and company performance in the warehouse industry. Although Rogers et al. [37] provided empirical evidence of the importance of IT in quality performance, the role of IT in TQM environments was not investigated. Torkzadeh and Doll [38] devised and applied a construct to measure the perceived impact of IT on work (i.e. only one of the eight TQM dimensions). 
The only consideration given to how IT influences TQM is the reference model developed by Forza [39] to link TQM practices, information systems and quality performance through empirical research. However, using his own model and associated measures, Forza [40] did not succeed in empirically establishing a link between TQM practices and IT and only the use of IT in the quality assurance aspect of TQM was explored. Forza [40] proposed that the contribution of IT should be further investigated by developing adequate measures especially with reference to its use. More recently, Dewhurst et al. [41], have suggested that IT support TQM by improving costumer and supplier relationship, increasing process control, facilitating teamwork, facilitating inter departmental information flow, improving design process and skills and applying preventive maintenance.

To develop a measurement construct it is necessary to state the hypotheses to be tested and this requires an underlying theoretical framework. The framework shown in Figure 2 was developed by the authors after a case study analysis on fourteen companies [41]. The relationships espoused in the framework are explained as follows:

- Previous research [42] has shown that the application of TQM can be affected by variables such as company size or type of production system. In this paper the company characteristics that have been analysed include: company size, the importance of quality to compete and the type of manufacturing process (e.g. Job shop, Assembly line, Continuous production, Cellular or Fixed).

- More advanced companies will make a bigger use of IT and will also apply TQM. Therefore, a positive relationship between both variables can be expected.

- If IT affects TQM, a bigger use of IT should be positively related with any impact of IT on TQM.

- If IT implementation is positive, it has to be related with company performance.

- TQM is expected to be positively related with company performance [43]. 
- A positive impact of IT on TQM dimensions should have a positive impact on company performance.

\section{Methodology}

A postal questionnaire was used based on a previous multiple case study. The population comprised industrial companies with factories located in Spain. Industrial companies were chosen because the problems faced in the management of quality by service companies are different [44, 45]. A list of the 3000 largest Spanish companies by annual sales turnover is published by the organization "Fomento de la Producción" of which 1949 were surveyed. The target respondents of the questionnaire were quality managers. When the name of the quality manager was unknown, the questionnaire was addressed to "responsable de calidad" (quality leader) and the first question asked for the position of the respondent in the company.

The questionnaire response rate was 22.7\% (442 companies), and this is comparable to those of Operations Management studies by Frohlich and Dixon [46], Mehra and Inman [47], Small and Yasin [48] and Vickery et al. [49]. Some $60 \%$ of the companies in the sample are made up of Spanish companies, 21\% of other European Union companies. The majority of the questionnaires were answered by quality managers (70.5\%) whist other major respondents were quality department representatives (10.5\%) and plant directors (3.4\%). Respondents were also asked to indicate if they were using TQM or not; $52.9 \%$ of companies identified themselves as implementing TQM $(\mathrm{N}=234)$. Using the scores from this sub-sample of companies, a set of analyses of variance (ANOVAs) were performed on all items comprising TQM, IT impact on TQM, quality importance to compete and operational and quality performance to assess the impact of the respondent's position in the company on the responses. The ANOVAs results showed that respondent's perceptions among different groups were not significantly different for 61 of the 67 items considered. Only in six cases quality department members perceived a more 
optimistic situation than the quality manager and the operations/ production manager (see Table 2).

The measurement of most of the variables requires the definition of a scale because they cannot be measured directly and consequently 19 scales were developed (see Table 3 and Appendix).

According to Orlikowski and Gash [50] IT can be defined as "any form of computer-based information system, including mainframe as well as microcomputer applications.” A list of information technologies was obtained based on previous literature [51, 52, 53, 54, 55] (see Appendix). Information technologies were then classified into six broad categories (constructs) relating to their purpose of use: administrative IT, communications-related IT, decision support IT, production planning IT, product design IT, and production control IT. For instance, the administrative IT (ITADMN) construct pertains to IT used to assist in the more clerical and administrative tasks such as document organization, data organization and storage, data analysis, etc. This construct includes IT applications such as invoicing systems, stock control systems, payroll systems, databases and cost accounting systems. The communication-related IT construct (ITCOMM) refers to IT that is directly related to the transmission of information. This construct includes the following IT applications: advertising by a company web page, direct sales by a company web page, electronic data interchange (EDI), Intranet, and inter company networks and group working with electronic information interchange. The decision support IT (ITDEC) construct refers to the use of IT to support managers in the decision-making process. Subsequently, the decision support IT construct includes such IT applications as decision support systems, data analysis techniques and forecasting software. The production planning IT construct (ITPLAN) refers to the use of IT in production planning tasks, and therefore, includes such IT applications as Computer Aided Production Planning (CAPP), Manufacturing Requirements Planning (MRP), and Enterprise 
Resource Planning (ERP). The production design support IT (ITDESIGN) construct refers to the use of IT to assist in the product design process and include such IT applications as computer aided design (CAD), computer aided manufacturing (CAM), and computer aided engineering (CAE). The production control IT construct (ITPDCTRL) refers specifically to the use of IT in manufacturing activities and in quality control activities. This construct includes such IT applications as computerized numerical control machines (CNC), robots, electronic systems of quality control and flexible manufacturing systems (FMS). The TQM implementation construct was measured using a seven-item scale (see Appendix for measurement indicators) based on Martinez-Lorente's et al. [56] TQM definition (see Figure 1). Top management support was not included in the TQM implementation construct because it was considered that top management support is more of a necessary mechanism to implement TQM practices (e.g. customer relationships, supplier quality management, process flow management, workforce management, etc.) than a manifestation of TQM implementation in itself. Eight constructs were developed to measure the impact of IT on TQM (see Table 2 and Appendix for measurement indicators). Each one of these constructs refers to the impact of IT on each one of the eight TQM dimensions shown in Figure 1: impact of IT on top management support, impact of IT on workforce management, impact of IT on employees attitudes and behaviour, impact of IT on customer relationship, impact of IT on supplier relationship, impact of IT on product design process, impact of IT on process flow management and impact of IT on quality data and reporting.

Four indicators of company performance were used (see Table 2):

- Operational - different aspects of operational efficiency were subjectively measured by the respondents in relation to their industry (see Appendix).

- Quality - different aspects of quality were subjectively measured by the respondents in relation to their competitors (see Appendix). 
- Profitability on sales turnover (PST) - obtained from the Fomento de la Producción database.

- Profitability per employee (PE) - obtained from the Fomento de la Producción database.

All the items measuring TQM, IT, IT impact on TQM, operational and quality performance constructs were measured on a 1 to 5 scale where a score of 1 "no use at all” and 5 represented “intensive use”. The scores in each construct were averaged to obtain a composite measure for the construct. Reliability for the all the study's constructs was measured (see Table 3) using the internal consistency method, as described by Bohrnstedt [57]. Typically, reliability coefficients of 0.7 or more are considered adequate, however, coefficients of 0.6 can be accepted for new scales [58].

\section{RESULTS}

\section{Company characteristics and IT implementation}

The results show that company size is related with IT implementation. Number of employees and sales turnover are positive and significantly related with all the scales of IT implementation except for administrative work (see Table 4 and Figure 3). The use of IT for administrative work can be considered as less complex and more common. The results confirm that the extent of IT implementation depends on company size and the reason can be found in the fact that bigger companies have more qualified workers, which are necessary for the successful application of IT.

The process type does appear to be related to and influence the application of computerised production control (i.e. the ITPDCTRL), the IT most related with automation. An ANOVA test shows a level of significance of $p=0.02$. However, when the means of ITPDCTRL for each process type are analysed (see Table 5), it can be seen that the implementation of ITPDCTRL in a fixed position process is significantly lower than in the other types of processes (job shop, assembly line, continuous, and cellular) 


\section{Company characteristics and TQM implementation.}

Companies that apply TQM have a higher sales turnover and more employees and differences are significant at $\mathrm{p}<0.05$ as shown in Table 6 and Figure 4. However, the correlation between company size (measured by sales turnover and number of employees) and the extent to which TQM is implemented is not significant . This would indicate that size is an important factor in the decision of whether to apply TQM but when a company decides to do it, size is not an important issue.

The importance of quality in the industry should be an incentive to apply TQM. The data confirms this hypothesis and the mean of the level of the importance of quality is significantly bigger $(p=0.017)$ for companies that apply TQM (mean $=4.06)$ than for those that do not (mean $=3.93)$. Moreover, the level of application of TQM is correlated with the level of importance of quality to compete $(r=0.389, \mathrm{p}=0.000)$.

The type of process does not appear to affect the application of TQM. Although companies with assembly lines apply TQM more frequently (see Table 7), global differences are not significant (Chi-Square $=2.391, \mathrm{p}=0.664)$. Therefore, process type is not an important factor in the decision of implementing TQM in a company.

\section{IT and TQM implementation.}

TQM and IT implementation do not necessarily have to be correlated because they can be applied independently. However, we would expect to find that more advanced companies would introduce both IT and TQM. The data support this hypothesis, since means of application of the different dimensions of IT are all bigger when the company apply TQM (see Table 8 and Figure 5) and all differences are significant at $\mathrm{p}<0.05$. Moreover, correlations between the different dimensions of IT implementation and TQM implementation are positive and significant at $\mathrm{p}<0.01$ (see Table 9). 


\section{IT and IT impact on TQM.}

The impact of IT on TQM was measured on a 5- point scale. The composite means of seven of the eight TQM dimensions were above point 3 of the scale (see Table 10).

Therefore, the correlation between the level of IT implementation and the level of IT impact on TQM dimensions was evaluated. If IT has an impact on TQM, then it is reasonable to suppose that when IT is employed intensively, the perceived impact on TQM has to be greater. The data confirm this hypothesis because all the measures of the dimensions of IT are positive and significantly correlated $(\mathrm{p}<0.01)$ with the measures of IT impact on TQM dimensions (see Table 11 and Figure 5).

\section{TQM and company performance}

Companies that apply TQM have better operational performance and the difference in means is significant at $\mathrm{p}<0.05$. However, they have worse profitability on sales turnover (PST) and profit per employee (PE), although the differences are not significant at $\mathrm{p}<0.05$. Amongst companies that apply TQM, correlation between TQM implementation level and company performance also shows no conclusive results. There is a positive and significant correlation between TQM implementation and operational and quality performance but the correlation with profitability on sales turnover (PST) and profit per employee (PE) is not significant (see Table 12 and Figure 6).

\section{IT and company performance}

Operational and quality results are positive and significantly related with four measures of IT implementation: IT used for administrative work (ITADMN), IT used to communicate (ITCOMM), IT used as enablers in the decision making process (ITDEC) and IT used for the control of production systems (ITPDCTRL) (see Table 13). None of the measures of IT implementation were found to be related with profitability on sales turnover (PST) and profit per employee (PE). 


\section{IT impact on TQM and company performance.}

All the scales measuring IT impact on TQM are positive and significantly correlated with quality and operational performance but not with profitability on sales turnover (PST) and profit per employee (PE) (except supplier relationship) as shown in Table 14 and Figure 6.

\section{CONCLUSIONS}

This paper has analysed the impact of IT on TQM and several factors related with them. In order to test this relationship, six scales to measure different aspects of IT implementation were developed as well as eight scales to measure IT impact on the different TQM dimensions. All the scales were reliable according to Cronbach’s alpha criteria.

The data suggests that those companies who apply TQM perceive a larger impact of IT on their TQM dimensions. This suggests that IT acts in a supporting role for TQM. Moreover, IT and TQM implementation levels are positively related, suggesting that there are similar factors that make companies to implement IT and TQM. One of these factors could be attributed to the quality-oriented human resources elements, i.e. workforce management and employee attitudes and behavior, for two reasons:

- $\quad$ Today’s business environment requires managers to use more advanced technologies and management systems.

- $\quad$ More qualified employees have the necessary skills to use IT and to make the most of TQM.

The main findings of the other relationships have been analysed in this paper can be summarized as follows:

- Company size affects both TQM and IT implementation level. 
The use and implementation of management and work systems, even although these systems are generally accepted as positive for company results, depend on the quality of company resources, mainly human resources, and bigger companies have better access to the better resources.

- The type of production process has no significant effect on TQM or IT implementation. This suggests that managers perceive the benefits of TQM and IT irrespective of their production systems.

- The importance of quality to compete does affect the extent to which TQM is implemented. Therefore, companies believe that TQM helps them to improve quality but also they perceive some costs of TQM implementation and need an external incentive to decide to apply it

- The analysis of the effects of IT and TQM implementation on company performance give no conclusive results. The data showed significant and positive relationships among the level of IT and TQM implementation and operational and quality performance. However, we also found that IT and TQM implementation were not significantly related with profitability on sales turnover (PST) and profit per employee (PE).

The study has a number of limitations that give rise to a number of suggestions for future research. The lack of conclusive results in the analysis of the effects of IT and TQM implementation on company performance could be due to several reasons. One possible reason could be that PST and PE may not be the best "objective” financial measures to use for this purpose, since depreciation policies may vary considerably from company to company. Future research should try to use measures of financial performance that take into consideration this issue such as "value added per employee.” Another reason could be that the operational and quality performance were obtained from subjective opinions of managers, whereas the PST and PE are objective measures obtained from published financial data. 
Furthermore, optimistic managers might have given more points to every item of the questionnaire whilst pessimistic managers might have given less. However, this explanation would undermine most of the research based on questionnaires. A third reason could be found in the analysis of correlation amongst the variables, which shows that operational and quality performance are not correlated with profitability on sales turnover and that quality performance is not correlated with profit per employee. The explanation could be due to the fact that subjective scales are not affected by the industry factor since managers are asked to respond in relation to their competitors. The industry factor has not been considered for objective measures and this reason could hide the effect of TQM and IT on results. Our study was cross sectional of a given sample at a given point in time. A more stringent test of the relationships between IT, TQM, impact of IT on TQM, and performance requires a longitudinal study, or field experiment, which could gather information about IT, TQM, impact of IT on TQM, and company performance on an appropriate time span to enable further investigation of the association between the variation of factors and the variation of performance. 


\section{$\underline{\text { Appendix }}$}

\section{A.1. Information Technologies (IT) implementation.}

\begin{tabular}{|c|c|}
\hline Code & Construct / Survey Questions \\
\hline & $\begin{array}{l}\text { To what extent do you use ( } 1 \text { for no use at all and } 5 \text { for intensive use): } \\
\text { Administrative (ITADMN) }\end{array}$ \\
\hline Adm1 & Invoicing systems \\
\hline Adm2 & Stock control systems \\
\hline Adm3 & Payroll systems \\
\hline Adm4 & Data bases \\
\hline \multirow[t]{2}{*}{ Adm5 } & Cost accounting systems \\
\hline & Communication (ITCOMM) \\
\hline Com1 & Advertising by a company web page \\
\hline Com2 & Direct sales by a company web page \\
\hline Com3 & Company intranet (internal web) \\
\hline Com4 & Electronic data interchange (EDI) with suppliers \\
\hline Com5 & Electronic data interchange (EDI) with customers/clients \\
\hline \multirow[t]{2}{*}{ Com6 } & Group working with electronic information interchange \\
\hline & Decision support (ITDEC) \\
\hline Dsp1 & Decision support systems (DSS) \\
\hline Dsp2 & Data analysis techniques \\
\hline \multirow[t]{2}{*}{ Dsp3 } & Forecasting \\
\hline & Planning (ITPLAN) \\
\hline$P \ln 1$ & Computer Aided Production Planning (CAPP) \\
\hline Pln2 & Manufacturing Requirements Planning (MRP) \\
\hline \multirow[t]{2}{*}{ Pln3 } & Enterprise Resource Planning (ERP) for example SAP \\
\hline & Product design (ITDESIGN) \\
\hline Pds1 & Computer Aided Design (CAD) \\
\hline Pds2 & Computer Aided Manufacture (CAM) \\
\hline \multirow[t]{2}{*}{ Pds3 } & Computer Aided Engineering (CAE) \\
\hline & Production control (ITPDCTRL) \\
\hline Pdc1 & Numeric control machines with computer control (CNC) \\
\hline Pdc2 & Computers for controlling the factory floor \\
\hline Pdc3 & Robots \\
\hline Pdc4 & Electronic systems of product identification \\
\hline Pdc5 & Electronic systems of quality control \\
\hline Pdc6 & Flexible manufacturing systems (FMS) \\
\hline Pdc7 & Automated warehousing systems \\
\hline
\end{tabular}

\section{A.2. TQM implementation (TQM).}

Code Construct / Survey Questions

To what extent do you use TQM for: (1 for no use at all and 5 for intensive use):

TQM1 The management of information

TQM2 Workforce management

TQM3 The creation of positive work attitudes

TQM4 The relationships with suppliers

TQM5 Process flow management

TQM6 The relationships with customers

TQM7 New product design 
A.3. Impact of IT on TQM dimensions.

\begin{tabular}{|c|c|}
\hline Code & Construct / Survey Questions \\
\hline & $\begin{array}{l}\text { To what extent has IT been used to ( } 1 \text { for not at all and } 5 \text { for greatly): } \\
\text { Top management support }\end{array}$ \\
\hline Tms1 & Make the commitment to TQM visible to staff \\
\hline Tms2 & Facilitate communication between top management and employees \\
\hline Tms3 & Encourage employee involvement to improve work processes \\
\hline \multirow[t]{2}{*}{ Tms4 } & Communicate TQM values to employees \\
\hline & Customer relations \\
\hline Cr1 & Identify customers \\
\hline Cr2 & Identify customer needs \\
\hline Cr3 & Measure customer satisfaction \\
\hline $\mathrm{Cr} 4$ & Improve communications between you and the customer \\
\hline \multirow[t]{2}{*}{ Cr5 } & Analyse customer surveys \\
\hline & Supplier relationships \\
\hline Sup1 & Identify suppliers \\
\hline Sup2 & Improve ordering \\
\hline Sup3 & Improve communications between you and your suppliers \\
\hline Sup4 & Improve financial transactions between you and your suppliers \\
\hline \multirow[t]{2}{*}{ Sup5 } & Reduce the number of suppliers \\
\hline & Workforce management \\
\hline Wfm1 & Help to form work teams or quality improvement groups \\
\hline Wfm2 & Facilitate team working \\
\hline Wfm3 & Helped solicit suggestions from staff for quality improvement \\
\hline $\mathrm{Wfm} 4$ & Enabled staff to share task-related information \\
\hline Wfm5 & Supported the planning of staff training on quality issues \\
\hline Wfm6 & Supported the training of staff on quality issues \\
\hline Wfm7 & Helped to recognize staff contributions to quality improvement \\
\hline \multirow[t]{2}{*}{ Wfm8 } & Supported staff appraisal in quality improvement programmes \\
\hline & Employee attitudes and behaviour \\
\hline Eab1 & Employee motivation \\
\hline Eab2 & Employee loyalty \\
\hline Eab3 & Employee pride \\
\hline \multirow[t]{2}{*}{ Eab4 } & Helped to recognize employees' contributions to quality improvement \\
\hline & Product design process \\
\hline Pd1 & The design of experiments \\
\hline Pd2 & FMEA \\
\hline Pd3 & QFD \\
\hline \multirow[t]{2}{*}{$\mathrm{Pd} 4$} & The exchange of new design information between departments \\
\hline & Process flow management \\
\hline Pfm1 & Been used to detect the need for machine maintenance \\
\hline Pfm2 & Been used to check product adjust to design \\
\hline Pfm3 & Reduced process variance \\
\hline Pfm4 & Increased need for higher quality raw materials and components \\
\hline Pfm5 & Reduced the need for inspection activities \\
\hline \multirow[t]{2}{*}{ Pfm6 } & Facilitated the application of SPC \\
\hline & Quality information and analysis \\
\hline Qi1 & Collect data about employees, customers and suppliers \\
\hline Qi2 & Collect data about work/production processes \\
\hline Qi3 & Maintain quality information systems (e.g. documents) \\
\hline Qi4 & Provide DSS, statistical tools, diagrams \\
\hline Qi5 & Provide timely information to staff for decision-making \\
\hline Qi6 & Provide relevant information to staff that meets their needs \\
\hline Qi7 & Improve accuracy of information \\
\hline
\end{tabular}




\section{A.4. Operational Performance (OP).}

\section{Code Construct / Survey Questions}

Indicate how your company compares to the competition in your industry on a global basis for the following company measures of performance ( 1 indicates no competitive at all and 5 indicates highly competitive)

Op1 Unit costs (e.g. of manufacturing)

Op2 Fast delivery

Op3 Flexibility to change volume

Op4 Cycle time (from receipt of raw materials to shipment)

Op5 Defective rates

\section{A.5. Quality Performance (QP).}

\section{Code Construct / Survey Questions}

Qp1 The quality of our products and services is superior to the competition on a global basis

Qp2 Our relations with our customers are superior to the competition on a global basis

Qp3 Our customers are satisfied with the quality of our products over the past three years

Qp4 In general, our plant's level of quality performance over the past three years has been low, relative to industry norms

\section{A.6. Importance of quality to compete.}

\begin{tabular}{ll}
\hline Code & Construct / Survey Questions \\
\hline & Please indicate your agreement with the following statements (1 totally disagree and 5 for totally agree): \\
Iqc1 & Quality is very important in our markets \\
Iqc2 & Our customers prefer low price than high quality \\
Iqc3 & Our customers primarily choose suppliers by quality. \\
Iqc4 & In our markets we perform well with low quality products \\
\hline
\end{tabular}

\section{A.7. Type of production process.}

\begin{tabular}{ll}
\hline Code & Construct / Survey Questions \\
\hline Please indicate, if appropriate, the production layouts used in your company: \\
• $\quad$ Process layout (job shop) \\
• Assembly line \\
• $\quad$ Continuous production \\
• $\quad$ Fixed position \\
\hline
\end{tabular}




\section{References}

[1] Bessen, J., 2002, Technology Adoption Costs and Productivity Growth: The Transition to Information Technology, Review of Economic Dynamics 5 (2), 443 - 469.

[2] Kagan, A., 1994, Information technology seen as key to productivity, Chemical Week 155 (2), 20-22.

[3] Kotha, S. and P. M. Swamidass, 2000. Strategy, advanced manufacturing technology and performance: empirical evidence from U.S. manufacturing firms, Journal of Operations Management 18 (3), 257-277.

[4] Torkzadeh, G. and W. J. Doll, 1999, The development of a tool for measuring the perceived impact of information technology on work, Omega 27 (3), 327-339.

[5] Weston, F. C. Jr., 1993, Weighing 'soft' and 'hard' benefits of information technology, Manufacturing Systems 11 (7), 120-121.

[6] Mahmood, M. A. and G. J. Mann, 1993, Measuring the organizational impact of information technology investment: An exploratory study, Journal of Management Information Systems 10 (1), 97-122.

[7] Swamidass P. M. and S. Kotha, 1998, Explaining manufacturing technology use, firm size and performance using a multidimensional view of technology, Journal of Operations Management 17 (1), 23-37.

[8] Willcocks, L. P. and S. Lester, 1997, In search of information technology productivity: Assessment issues, Journal of the Operational Research Society 48 (11), 1082-1094.

[9] Brynjolfsson, E. and L. Hitt, 1996, Paradox lost? Evidence on the returns to information systems spending, Management Science 42 (4), 541-558.

[10] Dewan, S. and C. Min, 1997, The substitution of information technology for other factors of production: a firm-level analysis, Management Science 43 (2), 1660-1675. 
[11] Kelley, M. R., 1994, Productivity and information technology: the elusive connection, Management Science 40 (1), 1406-1425.

[12] Loveman, G. W., 1994, An assessment of the productivity impact of information technologies, in: T. J. Allen and M. S. Scott Morton, eds., Information technology and the corporation of the 1990s, Oxford University Press, New York, 84-110.

[13] Powell, T. C. and A. Dent-Micalef, 1997, Information technology as competitive advantage: the role of human, business, and technology resources. Strategic Management Journal 18 (5), $375-405$

[14] Strassmann, P. A., 1997, The squandered computer: evaluating the business alignment of information technologies, The Information Economics Press, New Canaan, Connecticut.

[15] Dewan, S. and K. L. Kraemer, 2000, Information technology and productivity: evidence from country-level data, Management Science 46 (4), 548-562.

[16] Ahire, S. L., D. Y. Golhar and M. A. Waller, 1996, Development and validation of TQM implementation constructs, Decision Sciences 27 (1), 23-56.

[17] Flynn, B. B., R. G. Schroeder and S. Sakakibara, 1994, A framework for quality management research and an associated measurement instrument, Journal of Operations Management 11 (4), 339-366.

[18] Saraph, J. V., P. G. Benson and R. G. Schroeder, 1989, An instrument for measuring the critical factors of quality management, Decision Sciences, 20 (4), 810-829.

[19] EFQM, 1998, Self-Assessment 1998 Guidelines for Companies. European Foundation for Quality Management, Brussels.

[20] NIST, 1995, Award Criteria. Malcolm Baldrige National Quality Award. U.S. National Institute of Standards and Technology, Gaitherburg, MD.

[21] Dale, B. G., R. J. Boaden and D. M. Lascelles, 1994, Total quality management: an overview, in: B. G. Dale, ed., Managing quality, Prentice Hall International, 3-40. 
[22] Bohoris, G.A. 1995, A comparative assessment of some major quality awards, International Journal of Quality and Reliability Management 12 (9), 30-43.

[23] Ayers, J. B., 1993, TQM and information technology: Partners for profit, Information Strategy: The Executive's Journal 9 (3), 26-31.

[24] Zadrozny, M. A. and K. E.Ferrazzi, 1992, Building a technology base for TQM. Chief Information Officer Journal 5 (2), 16-21.

[25] Berkley, B.J. and A. Gupta, 1994, Improving Service Quality with Information Technology, International Journal of Information Management, April (14), 109-121. [26] Cortada, J.W., 1995, TQM for Information Systems Management: Quality Practices for Continuous Improvement, McGraw-Hill, New York.

[27] Sobkowiak, R.T. and R.E. LeBleu, 1996, Repositioning HR Information Systems: Empowering Employees through Information, Information Systems Management Winter (13), $62-64$

[28] Pearson, J. M. and C. Hagmann, 1996, Status Report on Quality Assurance Methods, Information Systems Management winter (13), 52-57.

[29] Miller, H., 1996, The Multiple Dimensions of Information Quality, Information Systems Management spring (13), 79-82.

[30] Aiken, M., B. Hasan and M. Vanjani, 1996, Total Quality Management: A GDSS Approach Information Systems Management Winter (13), 73-75.

[31] Goodman, P.S., and E.D. Darr, 1996, Exchanging Best Practices through ComputerAided Systems, Academy of Management Executive 10 (2), 7-19.

[32] Khalil, O.E.M., 1996, Innovative Work Environments: The Role of Information Technology and Systems, SAM Advanced Management Journal 61 (3), 32-36.

[33] Kaplan, C., 1996, Technology to Ease Team-Based Quality Assessments, National Productivity Review 15 (3), 65-82. 
[34] Kock, N.F. Jr. and R.J. McQueen, 1997, Using Groupware in Quality Management Programs, Information Systems management, Spring (14), 56-62.

[35] Counsell, J., 1997, Using Technology to Involve the Workforce, Total Quality Management 8 (2 \& 3), 5l26-5l29.

[36] Byrd, T.A and T.E. Marshall, 1997, Relating Information Technology investment to Organisational performance: a causal model, Omega 25 (1), 43-56

[37] Rogers, D.S., P.J. Daugherty and A.E. Ellinger, 1996, The Relationship between Information Technology and Warehousing Performance, Logistics and Transportation Review 32 (4), 409-421.

[38] Torkzadeh, G and W.J. Doll, 1999, The development of a tool for measuring perceived impact of information technology on work, Omega 27 (3), 327-339

[39] Forza, C., 1995, Quality Information Systems and Quality Management: A Reference Model and Associated Measures for Empirical Research, Industrial Management and Data Systems 95 (2), 6-14.

[40] Forza, C., 1995, The Impact of Information Systems on Quality Performance: An Empirical Study. International Journal of Operations \& Production Management 15 (6), 9-83. [41] Dewhurst, F.W, A. R. Martínez-Lorente, and C. Sánchez-Rodríguez, 2003, An initial assessment of the influence of IT on TQM: a multiple case study, International Journal of Operations and Production Management 23 (4), 348-374.

[42] Martinez-Lorente, A.R., A. Gallego-Rodríguez and B.G. Dale, 1998, Total quality management and company characteristics: an examination, Quality Management Journal 5 (4), 59-71.

[43] Sousa, R. and C.A. Voss, 2002, Quality management revisited: a reflective review and agenda for future research, Journal of Operations Management 20, 91-109. 
[44] Dale, B.G., A.R.T. Williams, K.D. Barber and T. van der Wiele, 1997, Managing quality in manufacturing versus services: a comparative analysis. Managing Service Quality 7 (5), 242247.

[45] Benson, P.G., J.V. Saraph and R.G. Schroeder, 1991, The effects of organizational context on TQM: an empirical investigation. Management Science 37 (9), 1107-1124.

[46] Frohlich, M.T. and J.R. Dixon, 2001, A taxonomy of manufacturing strategies revisited, Journal of Operations Management 19 (5), 541-558.

[47] Mehra, S. and R.A. Inman, 1992, Determining the critical elements of just-in-time implementation, Decision Sciences 23 (1), 160-174.

[48] Small, M.H. and M.M. Yasin, 1997, Advanced manufacturing technology: implementation policy and performance, Journal of Operations Management 15 (4), 349-370 [49] Vickery, S.K., C. Dröge and R.E. Markland, 1997, Dimensions of manufacturing strength in the furniture industry, Journal of Operations Management, 15 (4), 317-330 [50] Orlikowski, W. and D. Gash, 1992, Changing frames: understanding technological change in organizations, Center for Information Systems Research, working paper, Massachusetts Institute of Technology.

[51] Bailey, J.E. and Pearson, S.W., 1983, Development of a tool for measuring and analysing computer user satisfaction, Management Science 29 (5), 530-545.

[52] Bakos, J.Y., 1987, Dependent Variables for the Study of Firm and Industry-Level Impacts of Information Technology, in Proceedings of the Eighth International Conference on Information Systems, December, Pittsburgh, USA. 10-23.

[53] Boyer, K.K., G. Keong Leong, P.T. Ward, and L. F. Krajewski, 1997, Unlocking the potential of advanced manufacturing technologies, Journal of Operations Management 15 (4), 331-347. 
[54] Premkumar G. and M. Roberts, 1998, Adoption of new information technologies in rural small business, Omega 27 (4), 467-484.

[55] Swamidass, P.M. And S. Kotha, 1998, Explaining manufacturing technology use, firm size and performance using a multidimensional view of technology, Journal of Operations Management 17 (1), 23-37.

[56] Martínez-Lorente, A.R., F.W. Dewhurst and A. Gallego-Rodríguez, 2000, Relating TQM, marketing and business performance: an exploratory study, International Journal of Production Research 38 (14), 3227-3246.

[57] Bohrnstedt, G. W., 1970, Reliability and validity assessment in attitude measurement, in: G. F. Summers (Ed), Attitude Measurement, Rand McNally \& Co., Chicago, 80-99.

[58] Nunnally, J. C., 1978, Psychometric theory, McGraw-Hill, New York. 


\begin{tabular}{|c|c|c|c|c|c|}
\hline & \multicolumn{5}{|c|}{ TQM models } \\
\hline & Saraph et al & Flynn et al & Ahire et al & MBNQA & EFQM \\
\hline $\begin{array}{l}\text { Top management } \\
\text { support }\end{array}$ & $\begin{array}{l}\text { Role of } \\
\text { divisional top } \\
\text { management } \\
\text { and quality } \\
\text { policy }\end{array}$ & $\begin{array}{l}\text { Top } \\
\text { management } \\
\text { support }\end{array}$ & $\begin{array}{l}\text { Top } \\
\text { management } \\
\text { commitment }\end{array}$ & Leadership & Leadership \\
\hline $\begin{array}{l}\text { Customer } \\
\text { relationship }\end{array}$ & - & $\begin{array}{l}\text { Customer } \\
\text { involvement: } \\
\text { customer } \\
\text { interaction }\end{array}$ & Customer focus & $\begin{array}{l}\text { Customer } \\
\text { focus and } \\
\text { satisfaction }\end{array}$ & $\begin{array}{l}\text { Customer } \\
\text { satisfaction }\end{array}$ \\
\hline $\begin{array}{l}\text { Supplier } \\
\text { relationship }\end{array}$ & $\begin{array}{l}\text { Supplier quality } \\
\text { management }\end{array}$ & $\begin{array}{l}\text { Supplier } \\
\text { involvement }\end{array}$ & $\begin{array}{l}\text { Supplier quality } \\
\text { management }\end{array}$ & $\begin{array}{l}\text { Process } \\
\text { management }\end{array}$ & Resources \\
\hline $\begin{array}{l}\text { Workforce } \\
\text { management }\end{array}$ & $\begin{array}{l}\text { Employee } \\
\text { relations }\end{array}$ & $\begin{array}{l}\text { Workforce } \\
\text { management }\end{array}$ & $\begin{array}{l}\text { Employee } \\
\text { involvement } \\
\text { Employee } \\
\text { training }\end{array}$ & $\begin{array}{l}\text { Human } \\
\text { development } \\
\text { and } \\
\text { management }\end{array}$ & $\begin{array}{l}\text { People } \\
\text { management }\end{array}$ \\
\hline $\begin{array}{l}\text { Employee } \\
\text { attitudes \& } \\
\text { behaviour }\end{array}$ & $\begin{array}{l}\text { Employee } \\
\text { relations }\end{array}$ & $\begin{array}{l}\text { Workforce } \\
\text { Management }\end{array}$ & $\begin{array}{l}\text { Employee } \\
\text { empowerment }\end{array}$ & $\begin{array}{l}\text { Human } \\
\text { development } \\
\text { and } \\
\text { management }\end{array}$ & $\begin{array}{l}\text { People } \\
\text { management }\end{array}$ \\
\hline $\begin{array}{l}\text { Product design } \\
\text { process }\end{array}$ & $\begin{array}{l}\text { New product } \\
\text { quality }\end{array}$ & Product design & $\begin{array}{l}\text { Design quality } \\
\text { management }\end{array}$ & $\begin{array}{l}\text { Process } \\
\text { management }\end{array}$ & - \\
\hline $\begin{array}{l}\text { Process flow } \\
\text { management }\end{array}$ & $\begin{array}{l}\text { Process } \\
\text { management } \\
\text { /operating } \\
\text { procedures }\end{array}$ & $\begin{array}{l}\text { Process } \\
\text { management }\end{array}$ & SPC useage & $\begin{array}{l}\text { Process } \\
\text { management }\end{array}$ & Process \\
\hline $\begin{array}{l}\text { Quality data and } \\
\text { reporting }\end{array}$ & $\begin{array}{l}\text { Quality data and } \\
\text { reporting }\end{array}$ & $\begin{array}{l}\text { Quality } \\
\text { information: } \\
\text { feedback }\end{array}$ & $\begin{array}{l}\text { Internal quality } \\
\text { information } \\
\text { usage }\end{array}$ & $\begin{array}{l}\text { Information } \\
\text { and analysis }\end{array}$ & - \\
\hline
\end{tabular}

Table 1. Key elements of TQM reported by Ahire et al, Flynn et al. Saraph et al, MBNQA and EFQM. 


\begin{tabular}{|c|c|c|c|c|c|c|c|c|c|c|}
\hline \multirow[b]{2}{*}{$\begin{array}{l}\text { Items } \\
\text { code }\end{array}$} & \multicolumn{7}{|c|}{ Respondent's position in the company } & \multirow[b]{2}{*}{ F-value } & \multirow[b]{2}{*}{ P-value } & \multirow[b]{2}{*}{ T-tests } \\
\hline & $\mathbf{A}$ & B & $\mathbf{C}$ & D & $\mathbf{E}$ & $\mathbf{F}$ & G & & & \\
\hline Qp1 & 4.40 & 4.00 & 3.91 & 3.83 & 4.25 & 4.26 & 3.79 & 2.26 & 0.039 & $\mathrm{~F}>\mathrm{D}^{*} ; \mathrm{F}>\mathrm{G}^{*}$ \\
\hline Qp2 & 4.00 & 3.75 & 3.73 & 3.67 & 3.75 & 4.23 & 3.54 & 2.40 & 0.028 & $\mathrm{~F}>\mathrm{D}^{*} ; \mathrm{F}>\mathrm{G}^{*}$ \\
\hline Qi1 & 4.20 & 3.75 & 3.27 & 3.45 & 3.25 & 4.26 & 3.54 & 3.59 & 0.002 & $\mathrm{~F}>\mathrm{C}^{*} ; \mathrm{F}>\mathrm{D}^{*} ; \mathrm{F}>\mathrm{E}^{*} ; \mathrm{F}>\mathrm{G}^{*}$ \\
\hline Qi2 & 4.20 & 3.75 & 3.82 & 3.60 & 4.00 & 4.26 & 3.88 & 2.17 & 0.047 & $\mathrm{~F}>\mathrm{D}^{*}$ \\
\hline Wfm5 & 3.20 & 3.00 & 3.45 & 3.08 & 3.00 & 3.74 & 3.46 & 2.31 & 0.035 & $\mathrm{~F}>\mathrm{D}^{*} ; \mathrm{F}>\mathrm{E}^{*}$ \\
\hline \multirow[t]{2}{*}{ Wfm6 } & 3.40 & 2.75 & 3.36 & 3.12 & 3.25 & 3.70 & 3.63 & 2.18 & 0.046 & $\mathrm{~F}>\mathrm{B}^{*} ; \mathrm{F}>\mathrm{D}^{*}$ \\
\hline & $\mathrm{N}=5$ & $\mathrm{~N}=4$ & $\mathrm{~N}=11$ & $\mathrm{~N}=156$ & $\mathrm{~N}=4$ & $\mathrm{~N}=23$ & $\mathrm{~N}=24$ & & & \\
\hline
\end{tabular}

Table 2. Influence of respondent's position on selected items.

Note: (A) President, owner or general manager; (B) General manager in Spain; (C) Plant director; (D) Quality department director/manager; (E) Operations/production department director/manager, (F) Quality department member; (G) Other

* Statistically significant at $p=0.05$

\begin{tabular}{|c|c|c|c|}
\hline Variable & Scale & No. of items & Cronbach's $\alpha$ \\
\hline \multirow[t]{6}{*}{ IT implementation } & ITADMN & 5 & 0.7395 \\
\hline & ITCOMM & 6 & 0.7048 \\
\hline & ITDEC & 3 & 0.7221 \\
\hline & ITPLAN & 3 & 0.8297 \\
\hline & ITDESIGN & 3 & 0.7490 \\
\hline & ITPDCTRL & 7 & 0.8003 \\
\hline TQM implementation & TQM & 7 & 0.8176 \\
\hline \multirow[t]{8}{*}{ IT impact on TQM dimensions } & Top management support & 4 & 0.8879 \\
\hline & Customer relationship & 5 & 0.8210 \\
\hline & Supplier relationship & 5 & 0.7781 \\
\hline & Workforce management & 8 & 0.9166 \\
\hline & Employee attitudes & 4 & 0.7767 \\
\hline & Product design process & 4 & 0.8288 \\
\hline & Process flow management & 6 & 0.8383 \\
\hline & Quality data \& reporting & 7 & 0.8706 \\
\hline \multirow[t]{4}{*}{ Company performance } & Operational performance & 5 & 0.6478 \\
\hline & Quality performance & 4 & 0.7259 \\
\hline & PST & 1 & - \\
\hline & $\mathrm{PE}$ & 1 & - \\
\hline \multirow[t]{4}{*}{ Company characteristics } & Number of employees & 1 & - \\
\hline & Sales volume & 1 & - \\
\hline & Type of production process & 1 & - \\
\hline & Importance of quality to compete & 4 & 0.6439 \\
\hline
\end{tabular}

Table 3. Variables, number of items, and reliability. 


\begin{tabular}{|c|c|c|c|c|c|c|}
\hline & ITADMN & ITCOMM & ITDEC & ITPLAN & ITDESIGN & ITPDCTRL \\
\hline Sales turnover & 0.072 & 0.150 & 0.151 & 0.125 & 0.107 & 0.211 \\
\hline & 0.065 & 0.001 & 0.001 & 0.005 & 0.014 & 0.000 \\
\hline No. Employees & 0.074 & 0.148 & 0.167 & 0.198 & 0.180 & 0.274 \\
\hline p & 0.060 & 0.001 & 0.000 & 0.000 & 0.000 & 0.000 \\
\hline
\end{tabular}

Table 4. Correlations between company size indicators and IT implementation.

\begin{tabular}{|l|l|l|l|l|l|}
\cline { 2 - 6 } \multicolumn{1}{c|}{} & \multicolumn{5}{c|}{ Type of production process } \\
\cline { 2 - 6 } \multicolumn{1}{c|}{ Job Shop } & Assembly Line & Continuous & Cellular & Fixed \\
\hline Number & 83 & 110 & 105 & 105 & 9 \\
\hline Mean & 2.5516 & 2.4948 & 2.5439 & 2.5287 & 1.4815 \\
\hline Std. Dev. & 0.9399 & 1.0232 & 0.8888 & 0.8004 & 0.5576 \\
\hline
\end{tabular}

Table 5. ITPDCTRL and type of production process.

\begin{tabular}{|c|c|c|}
\cline { 2 - 3 } \multicolumn{1}{c|}{} & \multicolumn{2}{c|}{ TQM implemented } \\
\cline { 2 - 3 } \multicolumn{1}{c|}{} & Yes & No \\
\hline Sales turnover & 33503.30 & 13224.95 \\
\hline No. Employees & 701.16 & 337.49 \\
\hline
\end{tabular}

Table 6. Mean company size and adoption of TQM.

\begin{tabular}{|l|c|c|c|}
\hline \multirow{2}{*}{$\begin{array}{l}\text { Type of } \\
\text { production process }\end{array}$} & \multicolumn{2}{|c|}{ TQM implemented } & \\
\cline { 2 - 3 } Job shop & YES & NO & Total \\
\hline \multirow{3}{*}{ Assembly line } & $51.2 \%$ & 41 & 84 \\
& $19.5 \%$ & $48.8 \%$ & $100 \%$ \\
& 65 & $21.0 \%$ & $20.2 \%$ \\
\hline \multirow{3}{*}{ Continuous } & $59.1 \%$ & 45 & 110 \\
& $29.5 \%$ & $40.9 \%$ & $100 \%$ \\
\hline \multirow{3}{*}{ Cellular } & 52 & $23.1 \%$ & $26.5 \%$ \\
\hline \multirow{3}{*}{ Fixed } & $49.5 \%$ & 53 & 105 \\
& $23.6 \%$ & $50.5 \%$ & $100 \%$ \\
& 55 & $27.2 \%$ & $25.3 \%$ \\
\hline \multirow{3}{*}{} & $51.4 \%$ & 52 & 107 \\
& $25.0 \%$ & $48.6 \%$ & $100 \%$ \\
& 5 & $26.7 \%$ & $25.8 \%$ \\
\hline & $55.6 \%$ & 4 & 9 \\
& $2.3 \%$ & $44.4 \%$ & $2.2 \%$ \\
\hline & $\mathbf{2 2 0}$ & $2.1 \%$ & $\mathbf{4 1 5}$ \\
& $\mathbf{5 3 \%}$ & $\mathbf{1 9 5}$ & $\mathbf{1 0 0} \%$ \\
& $\mathbf{1 0 0} \%$ & $\mathbf{4 7 \%}$ & $\mathbf{1 0 0 \%}$ \\
\hline
\end{tabular}

Table 7. Type of production process and adoption of TQM. 


\begin{tabular}{|c|c|c|c|c|c|c|}
\hline TQM & ITADMN & ITCOMM & ITDEC & ITPLAN & ITDESIGN & ITPDCTRL \\
\hline YES & 4.5778 & 3.0403 & 3.0862 & 3.2812 & 3.1033 & 2.7048 \\
NO & 4.4692 & 2.7186 & 2.7649 & 2.6970 & 2.7067 & 2.2994 \\
\hline Total & 4.5267 & 2.8893 & 2.9354 & 3.0109 & 2.9184 & 2.5136 \\
\hline
\end{tabular}

Table 8. Adoption of TQM and IT implementation.

\begin{tabular}{|c|c|c|c|c|c|c|}
\cline { 2 - 6 } \multicolumn{1}{c|}{} & ITADMN & ITCOMM & ITDEC & ITPLAN & ITDESIGN & ITPDCTRL \\
\hline TQM & 0.476 & 0.448 & 0.569 & 0.407 & 0.385 & 0.533 \\
\hline
\end{tabular}

Table 9. Correlations between TQM implementation and IT applications.

\begin{tabular}{|l|c|c|}
\hline TQM dimensions & Mean & Std. Dev. \\
\hline Top management support & 3.1094 & 0.8962 \\
Customer relationship & 3.3936 & 0.7713 \\
Supplier relationship & 3.3800 & 0.6722 \\
Workforce management & 3.0266 & 0.6584 \\
Employee attitudes & 3.2376 & 0.5277 \\
Product design process & 2.8251 & 0.9229 \\
Process flow management & 3.1099 & 0.7421 \\
Quality data \& reporting & 3.6464 & 0.6599 \\
\hline
\end{tabular}

Table 10. Mean and Standard deviation for IT impact on TQM dimensions.

\begin{tabular}{|l|c|c|c|c|c|c|}
\hline $\begin{array}{l}\text { IT impact on TQM } \\
\text { dimensions }\end{array}$ & ITADMN & ITCOMM & ITDEC & ITPLAN & ITDESIGN & ITPDCTRL \\
\hline Top management support & 0.340 & 0.362 & 0.472 & 0.339 & 0.282 & 0.363 \\
Customer relationship & 0.182 & 0.419 & 0.376 & 0.244 & 0.240 & 0.321 \\
Supplier relationship & 0.321 & 0.361 & 0.430 & 0.393 & 0.259 & 0.400 \\
Workforce management & 0.276 & 0.365 & 0.507 & 0.355 & 0.317 & 0.442 \\
Employee attitudes & 0.248 & 0.161 & 0.319 & 0.301 & 0.206 & 0.362 \\
Product design process & 0.219 & 0.441 & 0.501 & 0.388 & 0.528 & 0.515 \\
Process flow management & 0.169 & 0.278 & 0.431 & 0.266 & 0.285 & 0.469 \\
Quality data \& reporting & 0.378 & 0.314 & 0.506 & 0.300 & 0.207 & 0.353 \\
\hline
\end{tabular}

Table 11. Correlations between IT impact on TQM dimensions and IT implementation. 


\begin{tabular}{|c|c|c|c|c|c|}
\cline { 2 - 6 } \multicolumn{1}{c|}{} & & \multicolumn{3}{c|}{ Company performance } \\
\cline { 2 - 6 } \multicolumn{1}{c|}{} & & Operational & Quality & PST & PE \\
\hline TQM implementation & $\mathrm{r}$ & 0.356 & 0.405 & 0.019 & 0.041 \\
& $\mathrm{p}$ & 0.000 & 0.000 & 0.780 & 0.552 \\
\hline
\end{tabular}

Table 12. Correlations between TQM implementation and company performance.

\begin{tabular}{|l|c|c|c|c|c|c|c|}
\cline { 3 - 8 } \multicolumn{2}{c|}{} & \multicolumn{7}{c|}{ IT implementation } \\
\hline Company performance & & ITADMN & ITCOMM & ITDEC & ITPLAN & ITDESIGN & ITPDCTRL \\
\hline Operational & $\mathrm{r}$ & 0.226 & 0.209 & 0.210 & 0.073 & 0.053 & 0.151 \\
& $\mathrm{p}$ & 0.000 & 0.000 & 0.000 & 0.067 & 0.136 & 0.001 \\
\hline Quality & $\mathrm{r}$ & 0.266 & 0.226 & 0.242 & 0.087 & 0.074 & 0.172 \\
& $\mathrm{p}$ & 0.000 & 0.000 & 0.000 & 0.095 & 0.133 & 0.004 \\
\hline PST & $\mathrm{r}$ & -0.044 & 0.009 & -0.004 & 0.005 & -0.002 & -0.018 \\
& $\mathrm{p}$ & 0.186 & 0.427 & 0.468 & 0.457 & 0.485 & 0.358 \\
\hline PE & $\mathrm{r}$ & 0.027 & -0.007 & 0.007 & -0.019 & -0.046 & 0.020 \\
& $\mathrm{p}$ & 0.295 & 0.440 & 0.444 & 0.352 & 0.179 & 0.341 \\
\hline
\end{tabular}

\begin{tabular}{|l|c|c|c|c|c|}
\cline { 3 - 6 } \multicolumn{2}{c}{} & \multicolumn{4}{c|}{ Company performance } \\
\hline IT impact on TQM dimensions & & Quality & Operational & PST & PE \\
\hline Top management support & $\mathrm{r}$ & 0.365 & 0.318 & -0.002 & 0.024 \\
& $\mathrm{p}$ & 0.000 & 0.000 & 0.978 & 0.730 \\
\hline Customer relationship & $\mathrm{r}$ & 0.275 & 0.215 & 0.092 & 0.080 \\
& $\mathrm{p}$ & 0.000 & 0.001 & 0.184 & 0.244 \\
\hline Supplier relationship & $\mathrm{r}$ & 0.208 & 0.140 & 0.121 & 0.176 \\
& $\mathrm{p}$ & 0.002 & 0.035 & 0.078 & 0.010 \\
\hline Workforce management & $\mathrm{r}$ & 0.403 & 0.302 & 0.067 & 0.078 \\
& $\mathrm{p}$ & 0.000 & 0.000 & 0.325 & 0.257 \\
\hline Employee attitudes & $\mathrm{r}$ & 0.342 & 0.184 & 0.047 & 0.036 \\
& $\mathrm{p}$ & 0.000 & 0.005 & 0.498 & 0.596 \\
\hline Product design process & $\mathrm{r}$ & 0.173 & 0.138 & 0.071 & 0.060 \\
& $\mathrm{p}$ & 0.010 & 0.042 & 0.312 & 0.393 \\
\hline Process flow management & $\mathrm{r}$ & 0.253 & 0.204 & 0.066 & 0.070 \\
& $\mathrm{p}$ & 0.000 & 0.002 & 0.339 & 0.310 \\
\hline Quality data \& reporting & $\mathrm{r}$ & 0.343 & 0.319 & 0.078 & 0.119 \\
& $\mathrm{p}$ & 0.000 & 0.000 & 0.253 & 0.081 \\
\hline
\end{tabular}

Table 14. Correlations of IT impact on TQM dimensions and company performance. 


\begin{tabular}{|l|l|}
\hline DIMENSIONS & DESCRIPTION \\
\hline Top management support & $\begin{array}{l}\text { Top management commitment is one of the major determinants of } \\
\text { successful TQM implementation. Top management has to be the first in } \\
\text { applying and stimulating the TQM approach and they have to accept the } \\
\text { maximum responsibility for their products and services. Top management } \\
\text { also has to provide the necessary leadership to motivate all employees. }\end{array}$ \\
\hline Customer relationship & $\begin{array}{l}\text { The needs of customers and consumers and their satisfaction have always } \\
\text { to be in the mind of all employees. It is necessary to identify these needs } \\
\text { and their level of satisfaction. }\end{array}$ \\
\hline Supplier relationship & $\begin{array}{l}\text { Quality is a more important factor than price in selecting suppliers. Long- } \\
\text { term relationships with suppliers have to be established and companies } \\
\text { should collaborate with suppliers to help improve the quality of } \\
\text { products/services. }\end{array}$ \\
\hline Workforce management & $\begin{array}{l}\text { Workforce management has to be guided by the principles of: training, } \\
\text { empowerment of workers and teamwork. Plans for recruitment and } \\
\text { training have to be implemented and workers need the necessary skills to } \\
\text { participate in the improvement process. }\end{array}$ \\
\hline Employee attitudes \& behaviour & $\begin{array}{l}\text { Companies have to stimulate positive work attitudes, including loyalty to } \\
\text { the organisation, pride in work, a focus on common organisational goals } \\
\text { and the ability to work cross-functionally. }\end{array}$ \\
\hline Product design process & $\begin{array}{l}\text { All departments should participate in the design process and work } \\
\text { together to achieve a design that satisfies the requirements of the customer } \\
\text { subject to technical, technological and cost constraints of the company. }\end{array}$ \\
\hline Process flow management & $\begin{array}{l}\text { Housekeeping along the lines of the 5S concept. Statistical and non- } \\
\text { statistical improvement instruments should be applied as appropriate. } \\
\text { Processes need to be error proof. Self-inspection should be undertaken } \\
\text { using clear work instructions. Processes should be maintained under } \\
\text { statistical control. }\end{array}$ \\
\hline Quality data and reporting & $\begin{array}{l}\text { Quality information has to be readily available and the information should } \\
\text { be part of the visible management system. Records about quality } \\
\text { indicators have to be kept, including scrap, rework and cost of quality. }\end{array}$ \\
\hline
\end{tabular}

Figure 1. TQM dimensions.

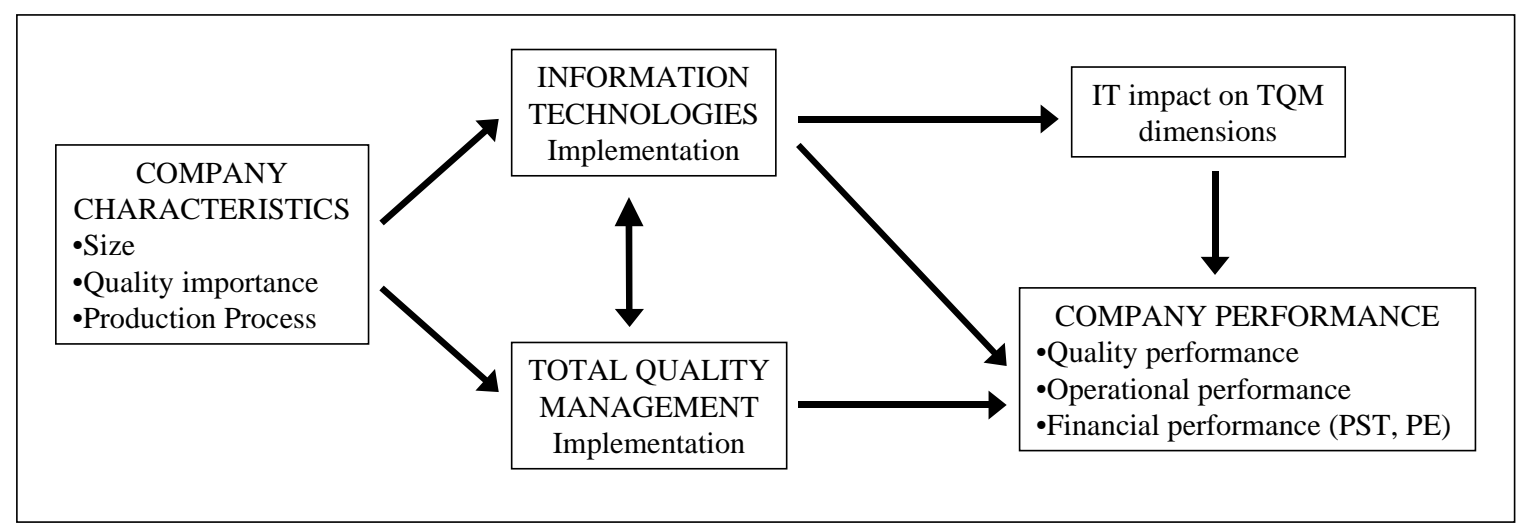

Figure 2. IT - TQM framework. 


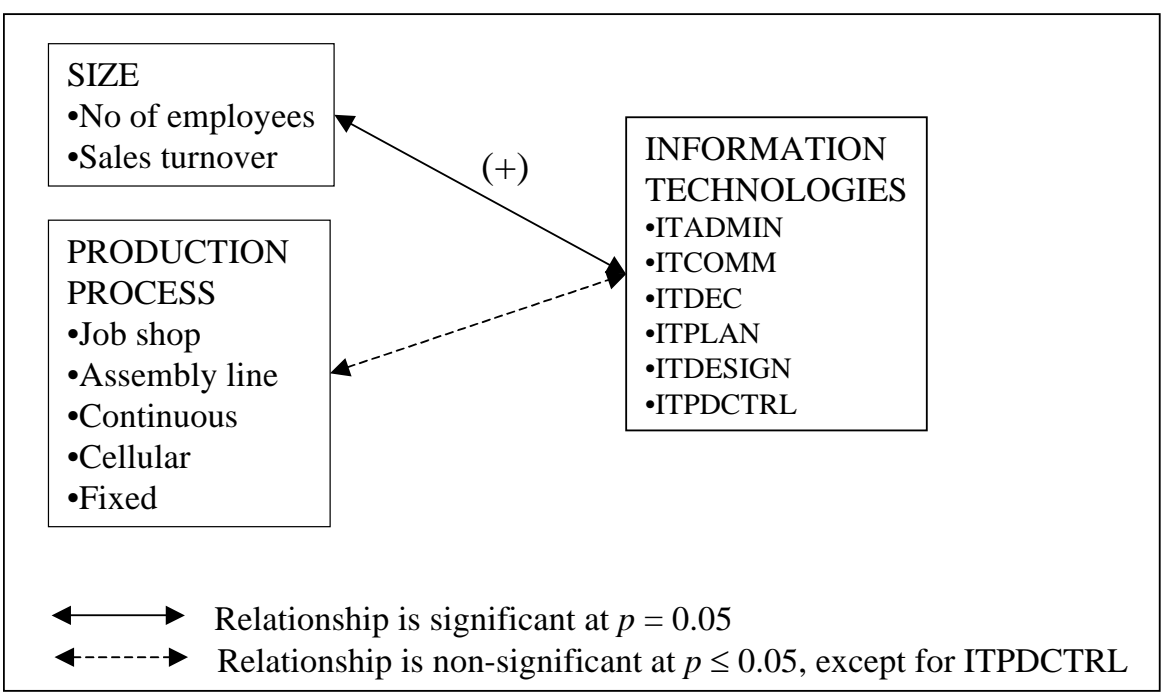

Figure 3. Company characteristics and IT implementation.

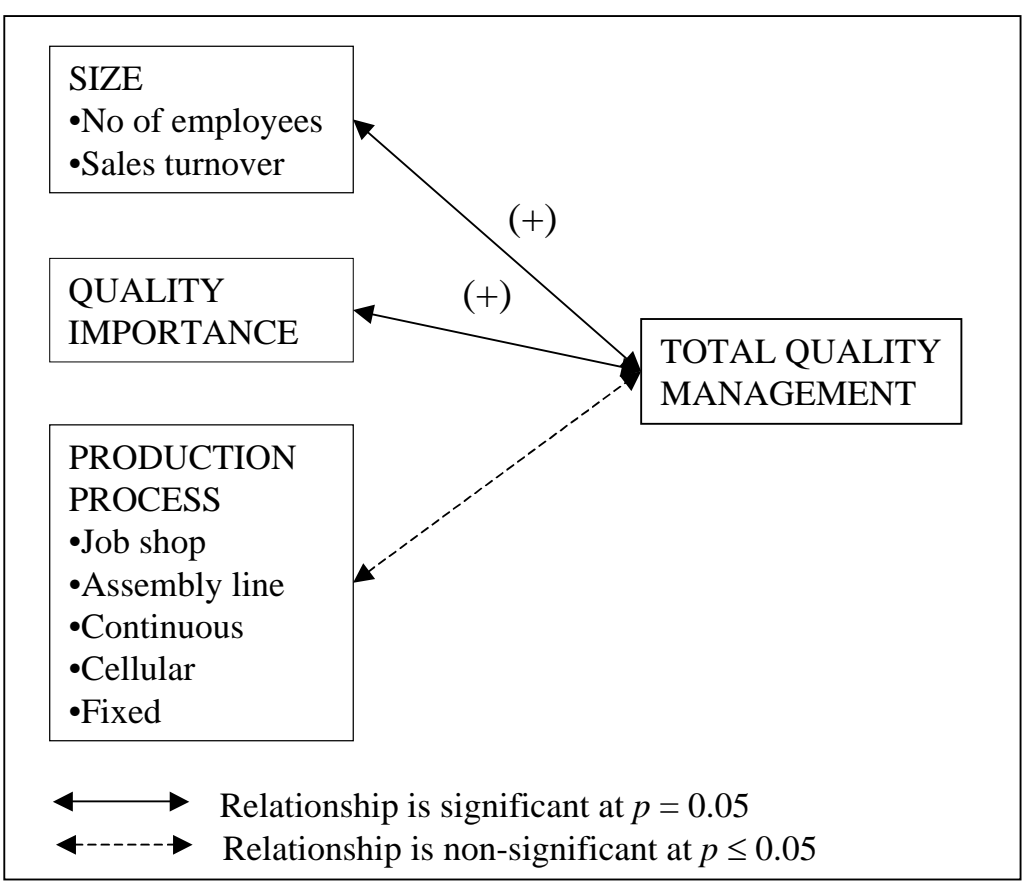

Figure 4. Company characteristics and TQM implementation. 


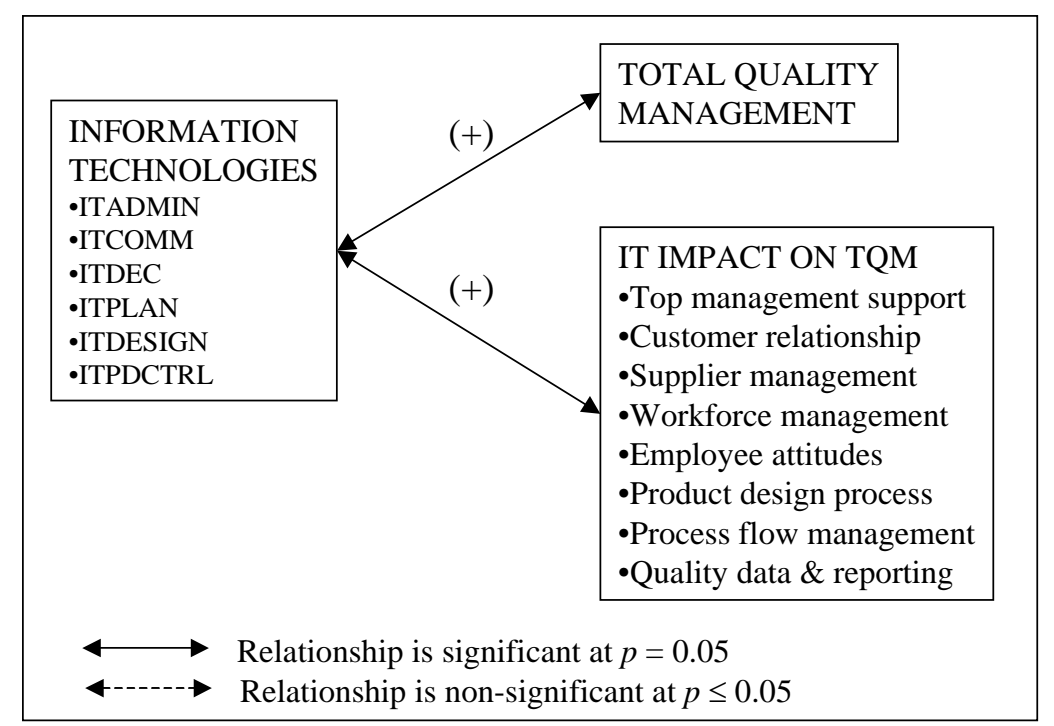

Figure 5. Relationships among IT, TQM and IT impact on TQM.

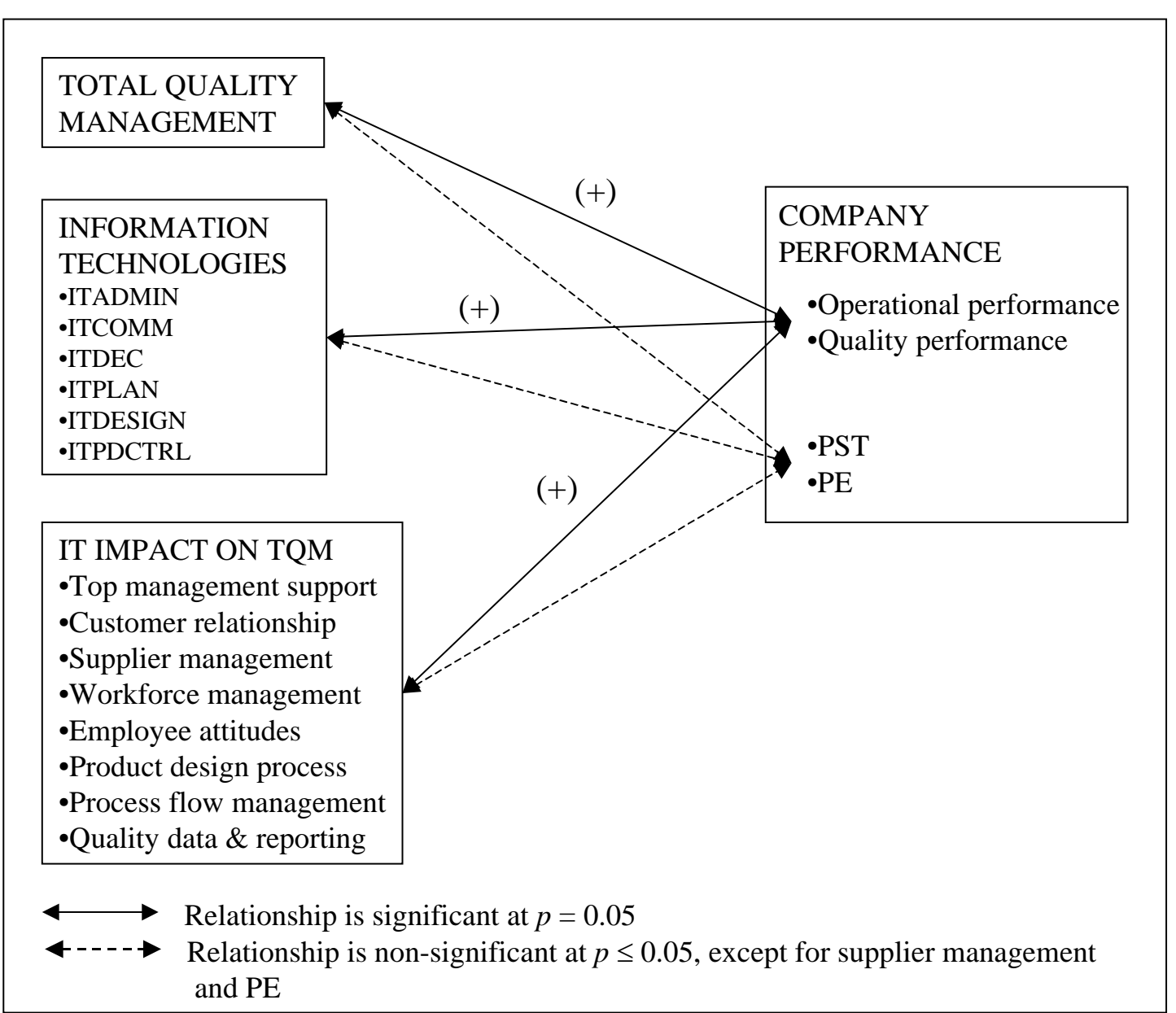

Figure 6. Relationships among IT, TQM, IT impact on TQM and company performance. 